\title{
GOVERNANCE BY COMMITTEE: \\ THE INFLUENCE OF BOARD OF DIRECTORS' COMMITTEE COMPOSITION ON CORPORATE PERFORMANCE
}

\author{
Alan E. Ellstrand \\ California State University - Long Beach \\ Long Beach, CA \\ Catherine M. Daily \\ Indiana University \\ Bloomington, IN \\ Jonathan L. Johnson \\ University of Arkansas \\ Fayetteville, AR \\ Dan R. Dalton \\ Indiana University \\ Bloomington, IN
}

\begin{abstract}
Although a considerable amount of attention has been devoted to examining the relationships between board of directors' composition and corporate financial performance, the vast majority of this research has focused on the board-atlarge. Such a focus may be unfortunate, as a great deal of board decision-making occurs at the committee level. This study examines the relationship between the composition of three important board of directors' committees (audit, compensation, nominating) and firm performance. Relying on multiple measures of board composition, multiple measures of corporate financial performance, and multiple time periods, we find no evidence of systematic relationships between board committee composition and corporate financial performance.
\end{abstract}

\section{Introduction}

Board of directors' composition has been the subject of a considerable amount of attention from both organizational researchers and the practitioner community in recent years. A primary focus of researchers has been the relationship between board composition and corporate financial performance (e.g., Boeker \& Goodstein, 1993; Cochran, Wood \& Jones, 1985; Dalton, Daily, Ellstrand, \& Johnson, 1998; Davis, 1991; Judge \& Zeithaml, 1992; Kesner, 1987; Mallette \& Fowler, 1992; Schmidt, 1975, 1977; Vance, 1983), as well as corporate survival (Chaganti, Mahajan \& Sharma, 1985; Daily \& Dalton, 1994a, 1994b; Daily \& Dalton, 1995). 
While there are a number of examinations of this relationship, extant research does not provide uniform prescriptions regarding which board composition configurations are associated with higher levels of performance (see Zahra \& Pearce, 1989 , for an overview of this issue). What is clear, however, is that in the contemporary business environment interested stakeholder groups are holding boards of directors increasingly accountable for corporate performance (Dobrzynski, 1992).

Important stakeholder groups, such as institutional investors, have devoted considerable resources to seeking reapportionment of corporate boards (e.g., Davis \& Thompson, 1994). These groups are relatively uniform in their demands for boards which are composed exclusively or predominately of outside, independent directors. The primary rationale behind these demands is a belief that independent boards will enhance firm performance (Biggs, 1995).

In addition to prescriptions regarding the composition of the board-at-large, shareholder groups and regulatory bodies have either mandated or suggested specific configurations for certain committees of the board of directors. While some of the strongest language from the practitioner community and regulatory groups regarding board composition has been directed at board committees, researchers have devoted far less attention to investigations of the relationship between committee composition and corporate financial performance, as compared to research developing linkages between composition of the board-at-large and corporate financial performance (see Bilimoria \& Piderit, 1994; Dalton et al., 1998). This may be unfortunate, as some observers have suggested that board committees are crucial to the efficiency of the overall board (Lorsch \& MacIver, 1989), and derivatively, to the firm.

\section{Theoretical Foundations}

Theorists have suggested that the board of directors' ability to positively influence corporate operations and outcomes may be based on the directors' independence from corporate management (Lorsch \& MacIver, 1989; Oviatt, 1988; Zahra \& Pearce, 1989). Much of the framework for this belief is found in agency theory (see Eisenhardt, 1989; Jensen \& Meckling, 1976, for an overview of agency theory). Agency theorists posit that board composition is especially relevant when ownership and control of the firm are disparate, as is the case in the modern business corporation (Fama \& Jensen, 1983). These theorists contend that a board composed predominately of independent, outside directors is needed to properly safeguard the interests of corporate owners (Fama \& Jensen, 1983).

By extension, these same concerns apply to important board committees. In fact, concerns regarding the extent to which directors are more sympathetic to corporate management as compared to shareholders may be even more salient for critical board committees. The agency problem largely addresses the directors' monitoring function. Board subgroups such as the compensation, audit, and nominating committees are central to effective monitoring. The compensation com- 
mittee, for example, is charged with structuring executive-level compensation packages which directly align managerial interests with those of shareholders. Effective monitoring via the audit committee helps ensure that the corporation remains a going concern. The nominating committee is responsible for identifying those director candidates who are likely to effectively discharge all director duties, including the monitoring role.

Director independence has largely been determined through board composition. Certain board composition configurations are believed to be more representative of independence than are others. Outside (non-management) directors, for example, are valued for their objectivity (Kesner, 1987; Mizruchi, 1983). Because of their potential for impartiality, outside directors may be better able to represent the interests of shareholders by acting as a part of a corporate check and balance system (Rechner \& Dalton, 1991). These advantages provided by outside directors offer a measure of independence to the board of directors as suggested by agency theorists. This position is also affirmed by shareholder groups who actively seek the appointment of independent, outside directors to the boards of firms in which they hold significant investments (Byrne, 1996; Dobrzynski, 1992).

As previously noted, to date, empirical work has not uniformly established the superiority of boards comprised predominately or exclusively of independent directors. While there are likely to be a variety of reasons for these sometimes contradictory findings, we have elected to focus on one specific explanation-the need for a focus on board committee composition. One commentator has suggested that a focus on the composition of the board-at-large "may be too subtle an indicator to adequately capture the importance of the outside director" (Daily, 1994: 285). We are persuaded by this observation and believe that analysis of board composition at the committee level may lead to a better understanding of directors' overall contribution to the firm, specifically firm performance.

Governance experts contend that board committees play an essential role in the corporate governance process (Carver, 1990; Lorsch \& MacIver, 1989; Vance, 1983; Worthy \& Neuschel, 1983). The full board, certainly in the typical large corporation, is generally too large and unwieldy for the efficient disposition of the vast majority of board decisions. Consequently, board committees, comprised of subsets of board members with specific expertise and a specific mandate, provide a means for more effective decision making. Committee decisions are then presented to the board-at-large for discussion and ratification (Bilimoria \& Piderit, 1994; Kesner, 1988; Lorsch \& MacIver, 1989).

\section{Director Independence and Board Committees}

Corporate governance advocates strongly endorse the board committee as a critical part of the corporate governance process. Committees help to facilitate the overwhelming information processing demands faced by corporate directors (Carver, 1990; Lorsch \& Maclver, 1989; Vance, 1983; Worthy \& Neuschel, 1983). 
As one director has noted, "If the whole board dwelt on every issue that the compensation or audit committee considers, we wouldn't have time to hold down jobs elsewhere" (Lorsch \& MacIver, 1989: 59). Since these subgroups focus on the committee's specific agenda, the committee level is where the majority of important board decisions are made.

In contrast to the many examinations of composition of the full board, few studies have analyzed the composition and contributions of board committees. Among the existing studies of board committees, two have focused on committee composition as a dependent variable. Kesner (1988) found that key committee composition tended to include more long-tenured outside directors with business backgrounds than the board as a whole. She also found that women tended to be underrepresented on the nominating and executive committees. Bilimoria and Piderit (1994) found that, after controlling for experience, women were underrepresented on the compensation, finance and executive committees, but were preferred for membership on the public affairs committee.

Other studies have examined corporate outcomes associated with board committees. Daily (1996), for example, investigated the relationship between audit committee composition and the incidence of a bankruptcy filing. She found no relationship between the percentage of affiliated directors on the audit committee and the incidence, type, or duration of corporate bankruptcy proceedings. O'Reilly, Main and Crystal (1988) examined the influence of social comparison theory in the determination of chief executive compensation. These researchers found that chief executive compensation was positively related to the compensation level of members of the compensation committee. In another compensation-related study, Singh and Harianto (1989) found that, contrary to their expectations, the proportion of inside directors on the compensation committee was negatively associated with the number of executives in a firm receiving golden parachute contracts. Finally, Tosi and Gomez-Mejia (1989) found that compensation committees were active monitors of chief executive compensation in both owner and managercontrolled firms.

The relatively modest attention to board committees by the academic community is in contrast to an increasing reliance on key board committees to facilitate the work of the overall board among the largest U. S. corporations. Three committees, in particular, have been identified as critical to directors monitoring function. These committees are the audit, compensation, and nominating committees. In addition to their importance, these committees are also among the most prevalent. A report by Heidrick and Struggles (1990) found that 99.2 percent of firms maintain an audit committee, 92.8 percent of firms rely on a compensation committee, and 60.4 percent of firms use a nominating committee (see also Anderson \& Anthony, 1986; Daily, 1996; Daily, Johnson, Ellstrand, \& Dalton, 1998). While the executive committee, too, is quite prevalent (e.g., Heidrick \& Struggles, 1965, 1990), we exclude this committee from our analysis because this committee is designed to be a consultative group and independence is less of an 
issue with regard to this committee. Independence on the audit, compensation, and nominating committees is of paramount importance, however. The following sections will illustrate how these three key board committees can facilitate the activity of the larger board and ultimately contribute to overall firm performance.

\section{Audit Committee}

Some observers have suggested that the audit committee is a critical safeguard in the corporate form of organization (Anderson \& Anthony, 1986; Daily, 1996; Lorsch \& Maclver, 1989). This committee is responsible for selecting the outside auditor, overseeing the preparation of the financial statements and annual reports, ensuring the efficacy of internal controls, and investigating allegations of material, financial, ethical and legal irregularities (Anderson \& Anthony, 1986). These activities, due to their complexity, are especially well-suited for action at the board committee level (Lorsch \& MacIver, 1989). An objective audit committee serves as one of the foundations for the board's overall control function.

As a result of its importance in ensuring the financial viability of the firm, as well as overseeing the reporting process, the independence of the audit committee is considered to be essential. As a measure of its importance, the Securities and Exchange Commission, the American Stock Exchange, and the National Association of Securities Dealers strongly suggest that corporate audit committees be composed of a majority of outside directors (Kesner, 1988). The New York Stock Exchange has adopted an even more aggressive stance, requiring that audit committee members be comprised exclusively of independent, outside directors (Donaldson, 1994).

Several benefits may be associated with an audit committee comprised of independent directors. Such a configuration may signal to shareholders that their interests are being properly safeguarded (Daily, 1996). In addition, a vigilant audit committee may act as an early warning system to alert the entire board to the potential for serious financial or legal problems before they fully develop. These important contributions may lead to improved firm performance. Consequently, we hypothesize:

Hypothesis 1: The percentage of independent directors serving on the audit committee will be positively associated with firm performance.

\section{Compensation Committee}

The compensation committee is another important board subgroup. This committee is responsible for establishing the level of compensation for senior corporate executives and corporate officers. In addition, the compensation committee is charged with recommending appropriate remuneration for corporate directors (Anderson \& Anthony, 1986; Fisher, 1986). Some compensation committees are also involved with the administration of stock option plans (Vance, 1983). The 
composition of the compensation committee is a crucial element in ensuring the administration of an equitable corporate reward system, thus contributing to the control role of the board (Fisher, 1986).

Determining an appropriate level of compensation for corporate executives and directors is a sensitive matter. Critical decisions must be made to determine the appropriate amount, type, and mix of pay to properly reward top executives (Finkelstein \& Hambrick, 1988). Directors with ties to management or the firm may be placed in a potentially difficult position. Here, the potential for personal loyalties to the chief executive officer, for example, may conflict with the directors' fiduciary responsibilities to shareholders. Thus, to avoid even the appearance of divided loyalties in setting executive compensation, governance advocates recommend placing only independent directors on the compensation committee (Anderson \& Anthony, 1986).

We would also note that the Internal Revenue Service mandates the placement of at least two outside directors on any given compensation committee (Kesner, 1994). A reward system with the proper executive incentives may encourage managerial actions that positively influence firm performance (Finkelstein \& Hambrick, 1988). Therefore we hypothesize:

Hypothesis 2: The percentage of independent directors serving on the compensation committee will be positively associated with firm performance.

\section{Nominating Committee}

The nominating committee is charged with the identification, selection, and evaluation of qualified candidates to serve in key positions within the corporation. More specifically, this committee is responsible for the selection of the chief executive officer, directors, and other top corporate executives (Vance, 1983). The nominating committee has become more active in influencing these critical personnel decisions in recent years (Lorsch \& MacIver, 1989). As one director noted, "[ $\mathrm{t}] \mathrm{h}$ CEO used to make most of the suggestions for new directors and tried to create a board 'in his own image,' but now this responsibility is shifting to the nominating committee..." (Lorsch \& MacIver, 1989: 21). The nominating committee may play a key role in the board's control function by selecting appropriate candidates to serve as directors and top corporate executives.

Nominating committee composition is crucial in ensuring that directors select the most qualified candidates for executive vacancies, as well as board openings. Independent directors may be more likely to make important personnel decisions based on merit, absent any influence as a result of internal political considerations. With their external focus, independent directors are also well positioned to be aware of the best candidates outside the organization to fill important executive-level positions. Moreover, a nominating committee that is composed of independent directors may be more likely to appoint other independent directors who will be vigilant in 
monitoring the CEO. Vigilant, independent directors may be more likely to lead to better overall corporate performance. Accordingly, we hypothesize:

Hypothesis 3: The percentage of independent directors serving on the nominating committee will be positively associated with firm performance.

Thus, our study seeks to examine the importance of the composition of these three vital board committees where the independence of the directors should be of greatest importance to the corporate governance process. The following sections discuss the methods we employed to test our hypotheses, our results and conclusions based on the study findings.

\section{Methods}

\section{Sample}

The sample for this study includes 200 publicly-traded firms randomly selected from the 1992 Fortune 500 listing. We selected these firms for a variety of reasons. First, a large proportion of the published studies which have investigated the relationship between board composition and corporate performance have relied on samples of large, publicly-traded firms (e.g., Cochran et al., 1985; Kesner, 1987; Rechner \& Dalton, 1991; Singh \& Harianto, 1989). Thus, to ensure comparability with other studies, we selected a sample similar to prior research in this area. In addition, as publicly-traded corporations, these firms are subject to the Securities Exchange Commission's public reporting requirements. As a result, data were readily available on committee composition, the nature of director relationships to the firm or firm management, and corporate performance. Lastly, these are the very type of firms which have received the greatest scrutiny regarding their corporate governance practices.

\section{Independent Variables}

Our review of the relevant corporate governance literature yields three operationalizations of board composition which differentially capture the extent to which directors maintain personal and/or professional relationships with the firm or firm management (e.g., Daily, Johnson \& Dalton, in press). Perhaps the most common approach for identifying those directors operating independently of the firm or firm management is the outside director distinction. This measure is traditionally comprised of those directors not currently employed by the focal organization (Schellenger, Wood \& Tashakori, 1989). The proportion of outside directors serving on the audit, compensation, and nominating committees, then, is the ratio of non-management to total directors on each of these committees.

A second approach for classifying directors relies on Securities and Exchange Commission (SEC) Regulation 14A, Item 6(b). Here, the directors' independence 
is determined by the extent to which they have personal and/or professional relationships with the firm, its subsidiaries, or firm management. These relationships are specifically identified by the SEC and range from immediate past employment with the firm to association with a law firm engaged by the organization (see Daily \& Dalton, 1994a for specific guidelines). These affiliated directors are arguably less independent than are non-management directors absent such ties. Relying on SEC 6(b) guidelines, we calculated the proportion of non-affiliated directors serving the audit, compensation, and nominating committees.

The third approach for classifying director independence relies not on the extent of personal and/or professional associations, but on the timing of the directors' appointments to the board (e.g., Wade, O'Reilly \& Chandratat, 1990). This distinction classifies those directors, regardless of their affiliations with the firm or firm management, as interdependent if they were appointed to the board during the tenure of the incumbent $\mathrm{CEO}$ and independent if their board appointment preceded the current CEO. Here, too, we calculate the proportion of independent directors serving the audit, compensation, and nominating committees of the board.

All board composition data were secured from corporate proxy statements filed with the SEC in 1992.

\section{Dependent Variables}

There is little agreement among organizational researchers concerning what constitutes an appropriate measure(s) of corporate performance (e.g., Cannella \& Lubatkin, 1993; Chakravarthy, 1986; Schellenger et al., 1989). Previous corporate governance research has typically relied on accounting measures such as return on equity ( $R O E$ ), return on investment ( $R O 1)$, and profit margin as indicators of corporate performance (e.g., Baysinger \& Butler, 1985; Cochran et al., 1985; Kesner, 1987; Pearce \& Zahra, 1992). Schellenger et al. (1989: 458), however, note a limitation of an exclusive reliance on accounting-based measures: "Non-market proxies do not measure the true financial performance of the corporation. The choice of inappropriate non-market proxy may even dictate the conclusions of the analysis."

In response to such criticisms, some researchers advocate a reliance on both accounting and market-based performance measures (Venkatraman \& Ramanujam, 1986). Additionally, recent research has included risk in the measurement of market-based performance (Cannella \& Lubatkin, 1993). Finance theory indicates that risk consists of two components: systematic risk - that is, the risk of the market - and unsystematic risk, that portion of the risk that is attributable to the firm (Brigham, 1985).

To most broadly capture firm performance, we include both accounting-based and market-based measures of corporate performance. The accounting-based measure, ROE, was selected to provide comparability to previous studies (e.g., Baysinger \& Butler, 1985; Cochran et al., 1985; Kesner, 1987; Pearce \& Zahra, 1992). These data were obtained from the COMPUSTAT database. Each firm's 
return on equity was adjusted for industry effects by subtracting industry $R O E$ for each firm from the focal firm's ROE. Industry aggregates were created from the COMPUSTAT industry classifications and aggregate data.

Market returns were assessed using each stock's beta. Beta provides information on how a stock performs relative to the overall market. A positive beta indicates that the stock tends to move in the same direction as the market; a negative beta stock tends to move against the market. A beta value greater than one describes a stock that is more volatile than the market while a beta value less than one indicates that the stock is less volatile than the market (Munn, Garcia \& Woelfel, 1993). Stock beta information was obtained from the Worldscope database.

A second measure of market return, Jensen's alpha, was also used as a performance indicator. This measure is the intercept term from the Capital Asset Pricing Model (CAPM). Jensen's alpha is a measure of the returns from holding a corporation's stock that are greater or smaller than the return adjusted for systematic risk, or the risk affecting all firms (Chatterjee \& Blocher, 1992). Jensen's alpha represents a firm's performance relative to that of an unmanaged portfolio of stocks of similar risk. A non-zero alpha implies that investors have revised their expectations about the firm's future cash flows (Cannella \& Lubatkin, 1993). Jensen's alpha was calculated using the regression equation on daily stock returns provided in Nayyar (1992).

An additional consideration relative to firm performance concerns the appropriate time lag required to properly evaluate the full influence of corporate initiatives (Day \& Lord, 1988). This concern is especially relevant to corporate governance studies since directors' influences on corporate strategic decisions may take several years to be fully realized. Thus to account for this potential time lag, the performance measures were examined annually over a three year period, beginning with a one-year lag, to better capture the prospective influence of board decisions.

\section{Control Variables}

We also provide three control variables commonly included in boards of directors research: firm size, industry classification, and board size. The log of total assets was employed as a measure of firm size. Values for firm assets were obtained through the COMPUSTAT database. A total of 14 industry groups were determined based on standard industry classification (SIC) codes. Finally, the board size was determined based on information included in corporate proxy statements.

\section{Analysis}

Hierarchical linear regression models were constructed to analyze the hypothesized relationships concerning board committee composition and firm performance. 


\section{Results}

Table 1 reports descriptive statistics and correlations for all study variables. This table indicates that the correlations between the three committee composition measures were high. Given the overlap of directors for these measures (i.e., strong reliance on non-management directors of differing types for each measure), this outcome is not surprising. Moreover, given the limited number of directors on any board there will necessarily be overlap in board committee assignments.

Tables 2 through 10 report the results of the regression models. Hypothesis 1 suggests that the percentage of independent directors serving on the audit committee will be positively associated with firm performance. The results of the regression analyses using Jensen's alpha as a performance measure are reported in Tables 2 through 4 . A significant association was found in only one instancethe three year lag between the proportion of independent directors on the audit committee and Jensen's alpha in year $t+3$ (three year lag). We would note, however, that this relationship is opposite the hypothesized direction. The results of the regression analyses for beta are reported in Tables 5 through 7 . None of the findings were significant. The results of the regression analyses relying on ROE are reported in Tables 8 through 10 . Here, too, no significant relationships were noted. Given that only one significant finding emerged from the 27 analyses conducted and this finding was opposite the direction hypothesized, the first hypothesis is rejected.

Hypothesis 2 stated that the percentage of independent directors serving on the compensation committee would be positively associated with firm performance. The results for Jensen's alpha are reported in Tables 2 through 4. The relationships between the proportion of outside directors and Jensen's alpha in the two-year lag $(t+2)$ and independent directors and Jensen's alpha in the threeyear lag $(t+3)$ are the only significant relationships. The results of the regression analyses for beta are reported in Tables 5 through 7 , and the results for ROE are reported in Tables 8 through 10 . In both cases no significant relationships were noted. Given that only two significant findings in support of the hypothesis emerged from the 27 analyses conducted, Hypothesis 2 is rejected.

Hypothesis 3 predicted that the percentage of independent directors serving on the nominating committee would be positively associated with firm performance. The results of the regression analyses for Jensen's alpha are reported in Tables 2 through 4 . As with the results for the audit committee, only one relationship - the three year lag for the proportion of independent directors - was significant. This relationship was opposite the direction hypothesized. The results of the regression analyses for beta are reported in Tables 5 through 7 , and the results for ROE are reported in Tables 8 through 10. In both cases no significant relationships were noted. Given that only one significant result was found among the 27 analyses conducted and this finding was opposite the hypothesized direction, Hypothesis 3 is also rejected. 
Table 1

Means, Standard Deviations and Correlations for Study Variables*

\begin{tabular}{|c|c|c|c|c|c|c|c|c|c|c|c|c|c|c|c|c|c|c|c|c|c|c|}
\hline Variable & Mean & SD & 1 & 2 & 3 & 4 & 5 & 6 & 7 & 8 & 9 & 10 & 11 & 12 & 13 & 14 & 15 & 16 & 17 & 18 & 19 & 20 \\
\hline 1. aindep & .56 & .36 & & & & & & & & & & & & & & & & & & & & \\
\hline 2. anonaff & .85 & .22 & .04 & & & & & & & & & & & & & & & & & & & \\
\hline 3. aout & .99 & .00 & .07 & $.26^{*}$ & & & & & & & & & & & & & & & & & & \\
\hline 4. cindep & .63 & 33 & $.77 * *$ & -.07 & .01 & & & & & & & & & & & & & & & & & \\
\hline 5. cnonaff & .82 & .23 & $.36^{*}$ & $.42 * *$ & -.12 & .04 & & & & & & & & & & & & & & & & \\
\hline 6. cout & .96 & .12 & .11 & .01 & .14 & .03 & $.46^{* *}$ & & & & & & & & & & & & & & & \\
\hline 7. nindep & .75 & .22 & $.68^{* *}$ & -.10 & -.05 & $.73^{* *}$ & .02 & .04 & & & & & & & & & & & & & & \\
\hline 8. nnonaff & .84 & .20 & -.03 & $.39 * *$ & -.06 & .02 & $.36 * *$ & .00 & -.02 & & & & & & & & & & & & & \\
\hline nout & .87 & .16 & -.11 & .13 & -.10 & -.05 & $.22 *$ & .08 & -.02 & $.63^{* *}$ & & & & & & & & & & & & \\
\hline 10. alpha92 & .00 & .00 & .08 & .03 & .01 & .02 & .04 & $.21 * *$ & .01 & -17 & -.00 & & & & & & & & & & & \\
\hline 11. alpha93 & .00 & .00 & .13 & .08 & $-.15^{*}$ & .06 & .13 & $.21 * *$ & .07 & -.08 & .02 & $.28 * *$ & & & & & & & & & & \\
\hline 12. alpha94 & .00 & .00 & $-.21^{* *}$ & -.07 & .08 & -.05 & -.02 & .02 & $.21^{*}$ & -.13 & -.06 & -.02 & -.03 & & & & & & & & & \\
\hline 13. beta 92 & .30 & .12 & .01 & .02 & .04 & -.01 & .11 & .05 & .11 & .04 & -.06 & .08 & $-.24 *$ & .01 & & & & & & & & \\
\hline 14. beta93 & .24 & .11 & .01 & .00 & .04 & .02 & .10 & .09 & .07 & .07 & .02 & $.22 * *$ & -.01 & -.09 & $.66^{* *}$ & & & & & & & \\
\hline 15. beta94 & .33 & .11 & -.06 & .06 & .01 & -.03 & .14 & -.04 & $.0 \mathrm{I}$ & .02 & .07 & $.23^{* *}$ & $.23^{*}$ & .14 & $.51^{* *}$ & $.46 * *$ & & & & & & \\
\hline 16. roe 92 & -7.07 & 37.84 & -.10 & -.10 & -.02 & .09 & -.11 & .00 & -.06 & -.11 & -.03 & .04 &. .04 & -.03 & $.14^{*}$ & $.15^{*}$ & .02 & & & & & \\
\hline 17. roe 93 & -.51 & 23.88 & -.01 & .05 & -.01 & .02 & -.15 & $-.21 * *$ & .10 & -.04 & -.05 & .04 & -.01 & -.08 & .05 & .12 & .05 & $.17 *$ & & & & \\
\hline 18. гое94 & 1.66 & 20.89 & -.07 & .07 & .01 & -.08 & -.03 & .06 & -.09 & -.02 & .06 & .05 & $.16^{*}$ & .10 & .04 & .06 & .11 & $.16^{*}$ & $.37 * *$ & & & \\
\hline 19. assets & 3.36 & .57 & .04 & .10 & .03 & .04 & .12 & .05 & .07 & .02 & .10 & -.06 & .06 & .03 & $.45^{* *}$ & $.42 * *$ & $.59^{* *}$ & .09 & .08 & .08 & & \\
\hline 21. bdsize & 11.46 & 2.91 & .10 & .04 & .05 & .11 & -.01 & .02 & .12 & -.03 & .03 & -.07 & .06 & -.06 & $.27 * *$ & $.22 *$ & $.28 * *$ & .07 & .01 & .11 & $.54 * *$ & \\
\hline
\end{tabular}

${ }^{*} p<.05$

$* * p<.01$

-Variable Legend:

1. aindep: percentage of independent directors on the audit committee

2. anonaff: percentage of non-affiliated directors on the audit committee

3. aout: percentage of outside directors on the audit committec

4. cindep: percentage of independent directors on the compensation committee

5. chonaff: percentage of non-affiliated directors on the compensation committee

6. cout: percentage of outside directors on the compensation committee

7. nindep: percentage of independent directors on the nominating committec

8. nnonaff: percentage of non-affiliated directors on the nominating committee

9. nout: percentage of outside directors on the nominating committec

1. alpha93: Jensen's alpha for 1993

12. alpha94: Jensen's alpha for 1994

13. beta92: stock beta for 1992

14. beta93: stock beta for 1993

15. beta94: stock beta for 1994

16. roe 92 ; industry-adjusted return on equity for 1992

17. roe 93 : industry-adjusted return on equity for 1993

18. roe94: industry-adjusted return on equity for 1994

10. alpha92: Jensen's alpha for 1992

19. assets: total assets in 1992

20. industry: industry classificalion

21. bdsize: number of directors on the board 
Table 2

Results of Regression Analyses: Jensen's Alpha Performance Measure

\begin{tabular}{|c|c|c|c|}
\hline & \multicolumn{3}{|c|}{ One Year Time Lag } \\
\hline & $\begin{array}{c}\text { Outside } \\
\text { Operationalization }\end{array}$ & $\begin{array}{c}\text { Non-Affiliated } \\
\text { Operationalization }\end{array}$ & $\begin{array}{c}\text { Independent } \\
\text { Operationalization }\end{array}$ \\
\hline \multirow{2}{*}{\multicolumn{4}{|c|}{$\begin{array}{l}\text { 1st Step: } \\
\text { Control Variables }\end{array}$}} \\
\hline & & & \\
\hline Total assets & -.032 & -.032 & -.032 \\
\hline Industry & -.031 & -.031 & -.031 \\
\hline Board size & -.051 & -.051 & -.051 \\
\hline \multicolumn{4}{|l|}{ 2nd Step: } \\
\hline \multicolumn{4}{|l|}{ Board Committee } \\
\hline Audit & -.013 & .089 & .166 \\
\hline Compensation & $.220^{*}$ & .089 & -.059 \\
\hline Nominating & -.017 & $-.235^{*}$ & -.055 \\
\hline $\mathrm{R}^{2}$ & .054 & .053 & .018 \\
\hline Adjusted $\mathrm{R}^{2}$ & .004 & .003 & -.034 \\
\hline F & 1.085 & 1.062 & .724 \\
\hline
\end{tabular}

Table 3

Results of Regression Analyses: Jensen's Alpha Performance Measure

\begin{tabular}{|c|c|c|c|}
\hline & \multicolumn{3}{|c|}{ Two Year Time Lag } \\
\hline & $\begin{array}{l}\text { Outside } \\
\text { Operationalization }\end{array}$ & $\begin{array}{c}\text { Non-Affiliated } \\
\text { Operationalization }\end{array}$ & $\begin{array}{c}\text { Independent } \\
\text { Operationalization }\end{array}$ \\
\hline \multirow{2}{*}{\multicolumn{4}{|c|}{$\begin{array}{l}\text { Ist Step: } \\
\text { Control Variables }\end{array}$}} \\
\hline & & & \\
\hline Total assets & -.013 & -.013 & -.013 \\
\hline Industry & $-.305 * *$ & $-.305 * *$ & $-.305^{* *}$ \\
\hline Board size & .077 & .077 & .077 \\
\hline \multicolumn{4}{|l|}{ 2nd Step: } \\
\hline \multicolumn{4}{|l|}{ Board Committee } \\
\hline Audit & -.161 & .047 & .189 \\
\hline Compensation & $.228^{*}$ & .174 & $-.04 ?$ \\
\hline Nominating & -.003 & -.158 & -.066 \\
\hline $\mathbf{R}^{2}$ & .163 & .134 & .112 \\
\hline Adjusted $\mathrm{R}^{2}$ & .119 & .089 & .066 \\
\hline $\mathbf{F}$ & $3.725^{* *}$ & $2.958^{*}$ & $2.417^{*}$ \\
\hline
\end{tabular}


Table 4

Results of Regression Analyses: Jensen's Alpha Performance Measure

\begin{tabular}{|c|c|c|c|}
\hline & & Three Year Time Lag & \\
\hline & $\begin{array}{c}\text { Outside } \\
\text { Operationalization }\end{array}$ & $\begin{array}{c}\text { Non-Affiliated } \\
\text { Operationalization }\end{array}$ & $\begin{array}{c}\text { Independent } \\
\text { Operationalization }\end{array}$ \\
\hline \multicolumn{4}{|l|}{$\begin{array}{l}\text { 1st Step: } \\
\text { Control Variables }\end{array}$} \\
\hline Total assets & .095 & .095 & .095 \\
\hline Industry & .010 & .010 & .010 \\
\hline Board size & -.113 & -.113 & -.113 \\
\hline \multicolumn{4}{|l|}{ 2nd Step: } \\
\hline Audit & .078 &. .035 & $-.326^{*}$ \\
\hline Compensation & -.030 & .032 & $.411^{* *}$ \\
\hline Nominating & -.056 & -.132 & $-.284^{*}$ \\
\hline $\mathbf{R}^{2}$ & .020 & .029 & .115 \\
\hline Adjusted $\mathbf{R}^{2}$ & -.031 & -.021 & .068 \\
\hline $\mathbf{F}$ & .400 & .580 & $2.482^{*}$ \\
\hline
\end{tabular}

Table 5

Results of Regression Analyses: Beta Performance Measure

\begin{tabular}{ccc}
\hline \multicolumn{3}{c}{ One Year Time Lag } \\
\hline Outside & Non-Affiliated & Independent \\
Operationalization & Operationalization & Operationalization
\end{tabular}

1st Step:

Control Variables

Total assets

Industry

Board size

$.443^{* *}$
.073
.028

$.443^{* *}$

$.443 * *$

.073

.073

.028

.028

2nd Step:

Board Committee

Audit

Compensation

Nominating

.001

$-.114$

$-.023$

.040

$-.157$

$-.115$

.092

.202

$\mathbf{R}^{2}$

.224

.043

.229

Adjusted $\mathrm{R}^{2}$

.184

.224

.189

F

$* p<.05$

$* * p<.01$ 
Table 6

Results of Regression Analyses: Beta Performance Measure

\begin{tabular}{|c|c|c|c|}
\hline & \multicolumn{3}{|c|}{ Two Year Time Lag } \\
\hline & $\begin{array}{c}\text { Outside } \\
\text { Operationalization }\end{array}$ & $\begin{array}{c}\text { Non-Affiliated } \\
\text { Operationalization }\end{array}$ & $\begin{array}{c}\text { Independent } \\
\text { Operationalization }\end{array}$ \\
\hline \multirow{2}{*}{\multicolumn{4}{|c|}{$\begin{array}{l}\text { Ist Step: } \\
\text { Control Variables }\end{array}$}} \\
\hline & & & \\
\hline Total assets & $.438 * *$ & $.438^{* *}$ & $.438 * *$ \\
\hline Industry & .077 & .077 & .077 \\
\hline Board size & .021 & -.021 & -.021 \\
\hline \multicolumn{4}{|l|}{ 2nd Step: } \\
\hline \multicolumn{4}{|l|}{ Board Committee } \\
\hline Audit & .007 & -.035 & -.030 \\
\hline Compensation & .075 & .092 & -.024 \\
\hline Nominating & -.036 & -.095 & .079 \\
\hline $\mathrm{R}^{2}$ & .189 &, 194 & .185 \\
\hline Adjusted $R^{2}$ & .146 & .152 & .142 \\
\hline $\mathrm{F}$ & $4.454 * *$ & $4.621 * *$ & $4.339 * *$ \\
\hline
\end{tabular}

Table 7

Results of Regression Analyses: Beta Performance Measure

\begin{tabular}{|c|c|c|c|}
\hline & \multicolumn{3}{|c|}{ Three Year Time Lag } \\
\hline & $\begin{array}{c}\text { Outside } \\
\text { Operationalization }\end{array}$ & $\begin{array}{l}\text { Non-Affiliated } \\
\text { Operationalization }\end{array}$ & $\begin{array}{c}\text { Independent } \\
\text { Operationalization }\end{array}$ \\
\hline \multicolumn{4}{|l|}{ 1st Step: } \\
\hline Total assets & $.598^{* *}$ & $.598 * *$ & $.598 * *$ \\
\hline Industry & -.116 & -.116 & -.116 \\
\hline Board size & -.042 & -.042 & -.042 \\
\hline \multicolumn{3}{|l|}{ 2nd Step: } & \\
\hline Audit & .011 & -.032 & -.110 \\
\hline Compensation & -.070 & .093 & .047 \\
\hline Nominating & .015 & -.017 & -.014 \\
\hline $\mathbf{R}^{2}$ & .364 & .366 & .367 \\
\hline Adjusted $\mathbf{R}^{2}$ & .331 & .332 & .334 \\
\hline $\mathrm{F}$ & $10.963^{* *}$ & $11.433^{* *}$ & $11.096 * *$ \\
\hline
\end{tabular}


Table 8

Results of Regression Analyses: ROE Performance Measure

\begin{tabular}{lccc}
\hline & \multicolumn{3}{c}{ One Year Time Lag } \\
\hline & $\begin{array}{c}\text { Outside } \\
\text { Operationalization }\end{array}$ & $\begin{array}{c}\text { Non-Affiliated } \\
\text { Operationalization }\end{array}$ & $\begin{array}{c}\text { Independent } \\
\text { Operationalization }\end{array}$ \\
1st Step: & & & \\
Control Variables & .050 & .050 & .050 \\
$\quad$ Total assets & -.108 & -.108 & -.108 \\
$\quad$ Industry & .052 & .052 & .052 \\
$\quad$ Board size & & & \\
2nd Step: & & & -.078 \\
Board Committee & -.017 & -.067 & -.029 \\
$\quad$ Audit & .005 & -.059 & -.011 \\
$\quad$ Compensation & -.037 & -.067 & .032 \\
$\quad$ Nominating & & & .018 \\
$\mathrm{R}^{2} \quad-022$ & .042 & .634 \\
Adjusted R & -.029 & -.008 & \\
$\mathrm{~F}$ & .423 & .837 & \\
\hline
\end{tabular}

$* p<.05$

$* * p<.01$

Table 9

Results of Regression Analyses: ROE Performance Measure

1st Step:

Two Year Time Lag

\begin{tabular}{|c|c|c|c|}
\hline & $\begin{array}{c}\text { Outside } \\
\text { Operationalization }\end{array}$ & $\begin{array}{c}\text { Non-Affiliated } \\
\text { Operationalization }\end{array}$ & $\begin{array}{c}\text { Independent } \\
\text { Operationalization }\end{array}$ \\
\hline \multicolumn{4}{|l|}{ Ist Step: } \\
\hline \multicolumn{4}{|l|}{ Control Variables } \\
\hline Total assets & .107 & .107 & .107 \\
\hline Industry & .046 & .046 & .046 \\
\hline Board size & -.048 & -.048 & -.048 \\
\hline \multicolumn{4}{|l|}{ 2nd Step: } \\
\hline \multicolumn{4}{|l|}{ Board Committee } \\
\hline Audit & .013 & .145 & -.120 \\
\hline Compensation & $-.211^{*}$ & $-.214^{*}$ & -.049 \\
\hline Nominating & -.048 & .030 & .223 \\
\hline $\mathrm{R}^{2}$ & .057 & .051 & .032 \\
\hline Adjusted $R^{2}$ & .008 &. .002 & -.018 \\
\hline $\mathrm{F}$ & 1.160 & 1.034 & .637 \\
\hline
\end{tabular}

$*_{\mathrm{p}}<.05$

${ }^{* *} \mathrm{p}<.01$ 
Table 10

Results of Regression Analyses: ROE Performance Measure

\begin{tabular}{|c|c|c|c|}
\hline & & Three Year Time Lag & \\
\hline & $\begin{array}{c}\text { Outside } \\
\text { Operationalization }\end{array}$ & $\begin{array}{c}\text { Non-Affiliated } \\
\text { Operationalization }\end{array}$ & $\begin{array}{c}\text { Independent } \\
\text { Operationalization }\end{array}$ \\
\hline \multicolumn{4}{|l|}{ 1st Step: } \\
\hline \multicolumn{4}{|l|}{ Control Variables } \\
\hline Total assets & -.003 & -.003 & -.003 \\
\hline Industry & -.172 &. .172 & -.172 \\
\hline Board size & .115 & .115 & .115 \\
\hline \multirow{2}{*}{\multicolumn{4}{|c|}{$\begin{array}{l}\text { 2nd Step: } \\
\text { Board Committee }\end{array}$}} \\
\hline & & & \\
\hline Audit & -.005 & .083 & -.043 \\
\hline Compensation & .056 & -.049 & .091 \\
\hline Nominating & .059 & -.032 & -.163 \\
\hline $\mathrm{R}^{2}$ & .048 & .046 & .059 \\
\hline Adjusted $\mathrm{R}^{2}$ & -.002 & -.003 & .010 \\
\hline $\mathrm{F}$ & .957 & .933 & 1.194 \\
\hline
\end{tabular}

\section{Discussion}

Contrary to expectations, these results suggest there is no systematic relationship between the independent director composition of the three key monitoring committees of the board and corporate financial performance. Notably, this finding is consistent regardless of the operationalization of director independence, the performance measure employed, or the time lag utilized. These results, however, are consistent with many of the studies examining the relationship between the composition of the larger board and firm performance (e.g., Boeker \& Goodstein, 1993; Davis, 1991; Judge \& Dobbins, 1995; Judge \& Zeithaml, 1992; Mallette \& Fowler, 1992; Schmidt, 1975, 1977).

Although agency theory provides a strong theoretical foundation in support of placing greater numbers of independent directors on key board committees, our findings suggest that board committee composition does not systematically influence corporate performance. There are several possible explanations that support our findings. First, it is possible that the compelling arguments in favor of independent directors are correct, but that the independent directors' objectivity and effective monitoring are counterbalanced by the need for information, time, and interest in firm operations provided by inside and affiliated directors. Independent directors, certainly those not employed in a management capacity with the focal firm, commonly face significant pressures from their responsibilities 
outside of the board room which may detract from their ability to contribute as directors. Many non-management directors, for example, serve as CEOs of other firms (Lorsch \& MacIver, 1989), clearly, a time-consuming job. Similarly, the expertise of inside directors may be offset by their lack of objectivity due to proximity to the CEO. These directors may feel compelled to support top management positions to protect or enhance their careers. Thus, while inside and outside directors may provide valuable service to the firm through their committee work, the simple designation as inside or outside director may have little influence on the quality of individual directors' contributions.

In addition, it is important to note that board committees may be too far removed from the center of daily decision making in the firm. As board researchers have established, even the most activist boards have been largely relegated to an oversight role (Lorsch \& MacIver, 1989). Moreover, the recommendations of board committees must be debated and approved by the full board before committee suggestions can be enacted. This process at the level of the full board may temper any suggestions/decisions made at the committee level. In addition, some observers have suggested that the influence of the board and its committees may be confined to direct incidents involving conflict between managers and stockholder's interests (Kosnik, 1987). Lastly, some researchers have noted the venuousness of the causal link between top management and firm performance (Murray, 1989). Perhaps these concerns are exacerbated at the board level.

Given that we find little evidence to support a systematic relationship between the composition of key board committees and corporate performance, it may be appropriate for researchers to focus future attention on the relationship between committee composition and specific strategic decisions. The board committees included in our examination are responsible for strategic corporate decisions including executive compensation and succession, merger and acquisition activity, and corporate restructurings. Perhaps the linkage to corporate performance is through these decisions. Future attention should also be focused on identifying other director demographic characteristics that may be associated with higher levels of firm performance. Finally, researchers should examine the processes that occur within key board committees to better understand the dynamics of the decision making processes that take place within these groups.

Corporate governance advocates continue to emphasize the importance of board and committee composition. A recent Business Week article, "The Best and Worst Boards," offered a lengthy list of recommendations to improve corporate governance practices. Included among the recommendations is the need for boards comprised of at best two or three inside directors, with remaining directors coming from outside the management ranks. A further recommendation is that the three committees included in our study - audit, compensation, nominating - be comprised exclusively of independent directors (Byrne, 1996). Despite the fact that we are unable to establish the performance advantages of this latter recommendation, our data suggest that corporate boards are taking this advice seri- 
ously. Our data indicate that the correlations between the composition of key committees, when relying of different measures of director independence, are very high. Further analysis of these data, however, demonstrate that the interrelationships between the composition of these three board committees is significantly lower when relying on measures of insider versus independent boards. This may suggest that firms are assigning their most independent directors however measured - to seats on important committees in accordance with the advice of governance experts and regulatory organizations.

\section{Conclusion}

Governance experts have empirically examined the relationship between board composition and firm performance for nearly 50 years (Dalton et al., 1998). We are at the same time perplexed by the inability to support consistently theorized linkages between independent boards and corporate performance and encouraged by the opportunity to continue rigorous investigation of this important governance issue. Furthermore, we are encouraged by the promise of investigating the extent to which board decisions moderate the relationship between the board and corporate financial performance. We hope this study serves to encourage other researchers along these same lines.

\section{References}

Anderson, C. A., \& Anthony, R. N. (1986). The new corporate directors. New York: John Wiley and Sons.

Baysinger, B. D., \& Butler, H. (1985). Corporate governance and the board of directors: Performance effects of changes in board composition. Journal of Law. Economics and Organization. 1, 101-134.

Biggs, J. (Nov. 1995). Why TIAA-CREF is active in corporate governance. The Participant. 2 .

Bilimoria, D., \& Piderit, S. K. (1994). Board committee membership: Effects of sexbased bias. Academy of Management Journal, 37, 1453-1477.

Boeker, W., \& Goodstein, J. (1993). Performance and successor choice: The moderating effects of governance and ownership. Academy of Management Journal. 36, 172 186.

Brigham, E. F. (1985). Financial management theory and practice. Chicago: The Dryden Press.

Byrne, J. A. (Nov. 26, 1996). The best and worst boards. Business Week: 82-106. 
Cannella, A. A., \& Lubatkin, M. (1993). Succession as a sociopolitical process: Internal impediments to outsider selection. Academy of Management Journal, 36, 763-793.

Carver, J. Boards that make a difference. (1990). San Francisco: Jossey-Bass Publishers.

Chaganti, R. S., Mahajan, V., \& Sharma, S. (1985). Corporate board size, composition, and corporate failures in the retailing industry. Journal of Management Studies. 22. 400-417.

Chakravarthy, B. S. (1986). Measuring strategic performance. Strategic Management Journal. $7,437-458$.

Chatterjee, S., \& Blocher, J. D. (1985). Measurement of firm diversification: Is it robust? Academy of Management Journal. 35, 874-888.

Cochran, P. L., Wood, R. A., \& Jones, T. B. (1985). The composition of boards of directors and the incidence of golden parachutes. Academy of Management Journal. 28, 664-671.

Daily, C. M. (1994). Bankruptcy in strategic studies: Past and promise. Journal of Management. 20, 263-295.

Daily, C. M. (1996). Governance patterns in bankruptcy reorganizations. Strategic Management Journal, 17, 355-375.

Daily, C. M., \& Dalton, D. R. (1994). Bankruptcy and corporate governance: The impact of board composition and structure. Academy of Management Joumal. 37, 1603-1617.

Daily, C. M., \& Dalton, D. R. (1994). Corporate governance and the bankrupt firm: An empirical assessment. Strategic Management Journal. 15, 643-654.

Daily, C. M., \& Dalton, D. R. (1995). CEO and director turnover in failing firms: An illusion of change? Strategic Management Journal, 16, 393-400.

Daily, C. M., Johnson, J. L., \& Dalton, D. R. On the measurements of board composition: If you have seen one, you certainly have not seen them all. Decision Sciences, (in press).

Daily, C. M., Johnson, J. L., Ellstrand, A. E., \& Dalton, D. R. (1998). Compensation committee composition as a determinant of CEO compensation. Academy of Management Journal. 41, 209-220.

Dalton, D. R., Daily, C. M., Ellstrand, A. E., \& Johnson, J. L. (1998). Meta-analytic reviews of board composition, leadership structure, and financial performance. Strategic Management Journal, 19, 269-290.

Day, D. W., \& Lord, R. G. (1988). Executive leadership and organizational performance: Suggestions for a new theory and methodology. Journal of Management. 14, 453-464. 
Davis, G. (1991). Agents without principles? The spread of the poison pill through the intercorporate network. Administrative Science Quarterly, 36, 583-613.

Davis, G. F., \& Thompson, T. A. (1994). A social movement perspective on corporate control." Administrative Science Quarterly. 39, 141-173.

Dobrzynski, J. H. (March 30, 1992). Calpers is ready to roar, but will CEO's listen? Business Week, 44-45.

Donaldson, W. H. (Fall, 1994). "Customize your governạnce." Directors and Boards, 811.

Eisenhardt, K. M. (1989). Agency theory: An assessment and sview. Academy of Management Review, 14, 57-74.

Fama, E. F., \& Jensen, M. C. (1983). Separation of ownership and control. Journal of Law and Economics, 26, 301-325.

Finkelstein S., \& Hambrick, D. C. (1988). Chief executive compensation: A synthesis and reconciliation. Strategic Management Journal, 9, 543-558.

Fisher, J. W. (Winter, 1986). Crafting policy for performance and rewards. Directors and Boards, 26-29.

Heidrick and Struggles, Inc. The changing board. Chicago: Heidrick and Struggles, 1965.

Heidrick and Struggles, Inc. The changing board. Chicago: Heidrick and Struggles, 1990.

Jensen, M. C., \& Meckling, W. H. (1976). Theory of the firm: Managerial behavior, agency costs and ownership structure. Journal of Financial Economics. 3, 305-360.

Judge, W. Q., \& Dobbins, G. H. (1995). Antecedents and effects of outside director's awareness of CEO decision style. Journal of Management, 21, 43-64.

Judge, W. Q., \& Zeithaml, C. P. (1992). Institutional and strategic cnoice perspectives on board involvement in the strategic decision process. Academy of Management Journal. 35, 766-794.

Kesner, I. F. (1987). Directors' stock ownership and organizational performance: An investigation of Fortune 500 companies. Journal of Management. 13, 499-507.

Kesner, I. F. (1988). Directors' characteristics and committee membership: An investigation of type, occupation, tenure and gender. Academy of Management Journal. 31 , 66-84.

Kesner, M. S. (Spring, 1994). The compensation committee's destiny. Directors and Boards, 35-38. 
Kosnik, R. D. (1987). Greenmail: A study of board performance and corporate governance. Administrative Science Quarterly, 32, 163-185.

Lorsch, J. W., \& MacIver, E. (1989). Pawns or potentates: The reality of America's corporate boards. Boston: Harvard Business School Press.

Mallette, P., \& Fowler, K. L. (1992). Effects of board composition and stock ownership on the adoption of 'poison pills.' Academy of Management Journal, 35, 1010-1035.

Mizruchi, M. S. (1983). Who controls whom? An examination of the relation between management and boards of directors in large American corporations. Academy of Management Review. 8, 426-435.

Munn, G. G., Garcia, F. L., \& Woelfel, C. J. (1993). Encyclopedia of banking \& finance. Pasadena, CA: Salem Press.

Murray, A. (1989). Top management group heterogeneity and firm performance. Strategic Management Journal, 10, 125-142.

Nayyar, P. R. (1992). Performance effects of three foci in service firms. Academy of Management Journal, 35, 985-1009.

O'Reilly, C. A., Main, B. G., \& Crystal, G. S. (1988). CEO compensation as tournament and social comparison: A tale ot two theories. Administrative Science Quarterly, 33 , 257-274.

Oviatt, B. (1988). Agency and transaction cost perspectives on the manager-shareholder relationship: Incentives for congruent interests. Academy of Management Review. 13, 214-225.

Pearce, J. A., \& Zahra, S. A. (1992). Board composition from a strategic contingency perspective. Journal of Management Studies. 29, 411-438.

Rechner, P. L., \& Dalton, D. R. (1991). CEO duality and organizational performance: A longitudinal analysis. Strategic Management Journal. 12, 155-160.

Schellenger, M. H., Wood, D. D., \& Tashakori, A. (1989). Board of directors composition, shareholder wealth and dividend policy. Journal of Management. 15, 457-467.

Schmidt, R. (1975). Does board composition really make a difference? The Conference Board Record, 12, 38-41.

Schmidt, R. (1977). The board of directors and financial interests. Academy of Management Journal. 20, 677-682. 
Singh, H., \& Harianto, F. (1989). Top management tenure, corporate ownership structure and the magnitude of golden parachutes. Strategic Management Journal. 10, 143156.

Tosi, Jr., H. T., \& Gomez-Mejia, L. R. (1989). The decoupling of CEO pay and performance: An agency theory perspective. Administrative Science Quarterly. 34, 169 189.

Vance, S. C. (1983). Corporate leadership: Boards, directors, and strategy. New York: McGraw-Hill.

Venkatraman, N., \& Ramanujam, V. (1986). Measurement of business performance in strategy research: A comparison of approaches. Academy of Management Review, $11,801-814$.

Wade, J., O'Reilly, C. A., \& Chandratat, I. (1990). Golden parachutes: CEOs and the exercise of social influences. Administrative Science Quarterly. 35, 587-603.

Worthy, J. C. \& Neuschel, R. P. (1983). Emerging issues in corporate governance. Evanston, IL: Northwestern University.

Zahra, S. A., \& Pearce, J. A. (1989). Board of directors and corporate financial performance: A review and integrative model. Journal of Management. 15, 291-334.

Alan E. Ellstrand is an Associate Professor in Strategic Management and International Business in the College of Business Administration at Califormia State University, Long Beach. He received his Ph.D. from Indiana University. His current research interests include corporate governance, top management teams and the influence of business on the national political process.

Catherine M. Daily is an Associate Professor of Strategic Management in the Kelley School of Business, Indiana University. She received her Ph.D. from Indiana University. Her research interests include corporate governance, strategic leadership, the dynamics of bankruptcy and business failure, and entrepreneurship.

Jonathan L. Johnson received his Ph.D. from Indiana University in 1995. He is currently an Assistant Professor at the Sam M. Walton College of Business Administration at the University of Arkansas. His current research interests include corporate governance and social networks within and between organizations.

Dan R. Dalton is Dean and Harold A. Poling Chair of Strategic Management at Indiana University. He received his Ph.D. from the University of California. His research interests include corporate governance, corporate social responsibility, managerial ethics and research methods. 